\title{
Research on Landless Peasant Sustainable Livelihood based on Data of Family Asset
}

\author{
Jiapeng Liu, ${ }^{1, a^{*}}$, Jie Liu ${ }^{1, b}$, Xiaoling Tang ${ }^{1, c}$ and Jinting $\mathrm{Wu}^{1, \mathrm{~d}}$ \\ ${ }^{1}$ China Jiliang University, Hangzhou, 310018, China \\ a jpliu@ cjlu.edu.cn, b1053614326@qq.com, ㄷ48089918@qq.com, ${ }^{d} 601674149 @ q q . c o m$
}

Keywords: landless peasant; urbanization; compensation; family asset; land acquisition.

\begin{abstract}
This paper concentrates on the problems of how landless peasants to optimize their family asset and makes a exploration to long-term sustainable livelihood of landless peasants. A field survey was carried in many regions of Zhejiang province. And according to the data, it comes to know the change of four kinds of family asset of landless family which called tangible asset, production asset, financing asset and human capital. In addition, there are lots of problems for landless peasants on optimizing their family asset. Those problems request all possible means to solve. Then it can help landless peasants realize long-term sustainable livelihood through optimizing their family asset reasonably.
\end{abstract}

\section{Introduction}

According to Zhejiang Provincial Bureau of Statistics data show that by the end of 2011, this would be it through the urbanization rate was $62.3 \%$, up 5.8 percentage points over 2006, higher than the national average of $11 \%$. Statistical data also shows "speed up the transfer of rural labor force". In 2011, there were $85.6 \%$ non-agricultural workers, which have increased $8.2 \%$ higher than in 2006. Continuous economic development accompanied by the rapid growth of urbanization, however, land acquisition and house demolition caused a significant increase in the number of landless farmers. At the same time,the improvement of the level of urbanization is mostly at the expense of farmers who had lost their land and other productive assets. In recent years, continuous improvement of resettlement standards, to some extent, have ensured the benefit of some landless peasants.

Statistics provided by Human Resources and Social Security Department of Zhejiang Province show that the institutional framework of social security of landless farmers in Zhejiang Province has been basically established by the end of 2006. Till 2011, there were 4.61 million landless peasants who have participated in Social Security, adding 2.27 million in 2006, with an increase of 97\%. Fight for landless peasants basic livelihood guarantee, the department ensure to do the follow "take as far as possible, take good protection immediately after land acquisition". However, due to the flaws of implementation and execution of the compensation standard, the majority of landless peasants interests are still subjected to some kind of violation and the landless peasants have faced the problems of sustainable livelihoods.

The structure of this paper is as follow. The second part of the paper makes reference to some the current literature, in order to clarify the definition of relevant concepts and leads to the significance and innovation of this paper. The third part of paper describes the theoretical assumptions and the data source. Based on the data and theory, fourth part of paper research the direction and amount of change to the landless peasant family assets during the process of land acquisition and house demolition. The fifth of the paper argues the specific reasons of the landless peasant family assets change. And the factors which affects the sustainable livelihood of landless peasants. The sixth part is going to show some practical suggestions to the landless peasants to optimize their family assert in a right way.

\section{Literature Review}

Domestic scholars have been concerning about the problems of compensation and resettlement to the landless peasant. Many scholars have also done lots of research of these issues. 
There are some current literature which concerned about the development scale an level of urbanization. Fang Hui-zhen and Hwang argued that new-typed urbanization have two main problem[1]. The first one is the inadequate industrial support. Another is the urbanization's mode and route which showed its core context that making the people transfer from rural to city realize. Gu Sheng-zu suggested that new-typed urbanization is the biggest engine of steady growth[2]. New-typed urbanization is also the development dividend after demographic dividend and the new start of reformation to set out again[3]. There are some research about the adjustment of the landless peasants' living standard and lifestyle during the land acquisition. Su Lung show an example of Nanning and do a field survey of the landless peasants living condition[4]. He came up with key way to how the landless peasant to make a living. Another scholar Sun Lu argued that community inclusion is the key point for the landless peasant to transfer to a citizen[5].

Focus on making a living an social security of the landless peasants, Huang Jian-wei and Yu Jie supposed that there are two helpful approaches to solve the sustainable livelihood of the landless peasants[6]. First one is to organize a plan to set a free training about vocation and technology for landless peasants. Another one is to produce a public policy to help landless peasants get jobs and according to the national regulations the certain department should give social security fees to landless peasants.

After making a research on the investment of rural households based on their family assert, Deng Da-song, Shi Jing, HU Hon-gwei found that the scale of rural household assert have significantly affected the health of their family members and insurance decision[7]. Poor farmers health status is relatively worse[8]. Song Ge Study China's farmers social guarantee problem inquiry[9]. Liu Xiaoxia study the problem of landless peasants in the China's urbanization process, [10].Huang Jianwei research the situation of farmer family balance of payments and give some Countermeasures[11]. Moreover, the possibility of the poor farmers who will continually participate in the rural endowment insurance and cooperative health insurance scheme would be lower.

The structure of this paper is as follow. After the introduction and literature review, the second part of paper describes the theoretical assumptions and the data source in order to clarify the definition of relevant concepts and leads to the significance and innovation of this paper. The third part of paper research the direction and amount of change to the landless peasant family assets during the process of land acquisition and house demolition based on the data and theory. The fourth of the paper argues the specific reasons of the landless peasant family assets change and the factors which affect the sustainable livelihood of landless peasants. The fifth part is going to show some practical suggestions to the landless peasants to optimize their family assert in a right way.

\section{Theory and data source}

According to Becker about home economics, the economic behavior of households can be abstracted to the household utility maximization problem. Through the reasonable hypothesis, the rural family assets can be divided into four types asserts which called the tangible assets, productive assets, financial assets and human capital. Tangible assets refer to the assert that family owned and real existent physical models. Such as real estate and agricultural production equipment. Production asset such as land is the most indispensable and basic carrier when farmers do productive activities. Financial assets are the cash and deposits and other financial investment assets that family owned. Human capital in the family is invisible but at the same time is an important asset which have large space to appreciate. Those four types of assets have a different contributions to the household utility. So when assessing household utility, it should accord with the actual situation. Maximizing the landless peasant household utility should follow the way that combining various family assert.

The project team made a survey in eleven prefecture level cities of Zhejiang Province by using sampling survey. According to the different urbanization to many regions in Zhejiang province, some typical regions would be extracted. The questionnaire focused on the basic family status, property status, income, investment and financing, welfare and evaluation for the landless farmers before and 
after land acquisition. The detail investigation provides a support for this paper to do theoretical analysis.

\section{Analysis the change of landless household asset}

According to the survey data of Zhejiang Province, the paper analyzes the change of four kinds asserts. It also analyzes that different change of assert how to make contribution to the landless peasants household utility.

First of all, the land is the important part of a farmer household assets in productive assets. Their land-based productive assets had a significant reduce and even become zero after land acquisition. There are the survey data in Table 1 which is showing the land area of 445 landless peasant households before urban transformation. But after land expropriation, the land of landless peasant families will be largely reduced or become zero. It means a significant reduction of productive assets. And according to different compensation methods and compensation standards, the land would convert to other forms of assets such as houses and other tangible assets or financial assets.

Table 1. Land area that landless peasant families owned before land acquisition

\begin{tabular}{ccc} 
Land area & Frequency & Percentage \\
\hline$\leq 1$ acre & 90 & $20.20 \%$ \\
1 acres $\sim 3$ acres & 193 & $43.30 \%$ \\
3 acres $\sim 6$ acres & 127 & $28.50 \%$ \\
$>6$ acres & 35 & $8 \%$ \\
Total & 445 & $100 \%$ \\
\hline
\end{tabular}

In addition, before the land acquisition, the majority of landless peasants depended on land as single and indispensable means of production in a long time. They also formed its unique mode of production and sources of income by combining their cultivated land with some of their family labor. Then made an increase of total household assert. After losing their cultivated land, landless peasants had difficulties to find a new job in a short time which would cut the main source of household income. Before land acquisition, there were $100.4 \%$ of respondents who made livings as farmers or workers. After that, the landless farmers have to face plight that how optimize their available human capital. However, under their limited conditions and bad external factors, its hard for landless peasants to find steady jobs. So human capital lost its capabilities to improve the family assert.

As the main tangible assets of landless family, house would be demolished as urban transformation. And they would obtain a certain of compensation on the basis of actual situation. Different ways of house demolition compensation enable landless peasant family assets changeable. For the transformation, the average of landless family housing area was $258.6 \mathrm{~m}^{2}$. But after field survey, the average of landless family housing area was $221.4 \mathrm{~m}^{2}$, which had a obvious decrease. There were five means of house demolition compensation as shown in Fig. 1. There were two most important compensations which were homestead and monetary compensation and housing and monetary compensation, accounting for $33 \%$ and $30 \%$. 


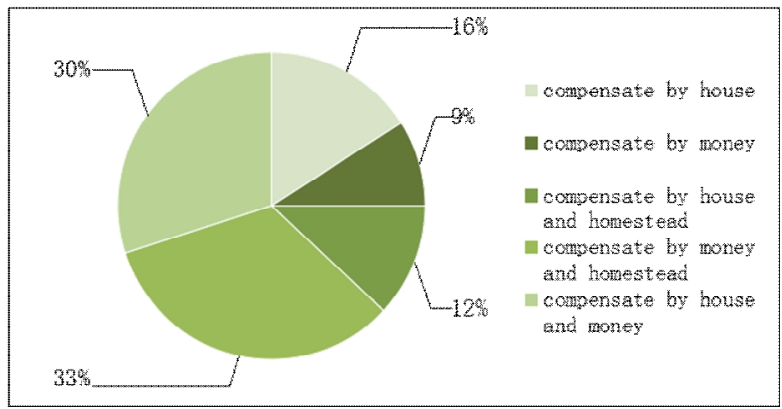

Fig. 1. Means of house demolition compensation

Another survey data also shown that total household assets average of landless family who have responded valued more than 650,000 yuan. While a year after the transformation, those family's total assets were more than 1.02 million yuan which have increased by $27.7 \%$. To some extent, the transformation process in urban and rural areas in Zhejiang Province, the total assets of responded family have a greater increase through optimizing their total household assets in the short term. But it is hard to estimate the long term situation.

\section{Investment decision and social security}

\section{At the Perspective of Family Investment Decision}

Cash or deposits of landless family would increase sharply with implementation of monetary compensation and other compensations. Optimizing the family financing asset reasonably would be conductive to sustainable livelihood of landless family. Seeing from survey data analysis in Fig. 2, however, landless farmers had difference decisions on using the monetary compensation. To improve live and buy houses are $37 \%$ and $35 \%$ which accounting for a large proportion. And there are only $8 \%$ landless families that use the monetary compensation to do a financing investment. Cause of the different landless peasants have various invest tendency, the data showed that $30 \%$ respondents would not take a stake in village enterprise. The reasons why landless would not do a financing investment or take a stake in village enterprise is various. There are two biggest concerned problems when respondents take some of their monetary compensation in village enterprise. One is poor management of those enterprises and the other is corruption. Two of them have accumulated more then $100 \%$ which is showing in Fig. 2.

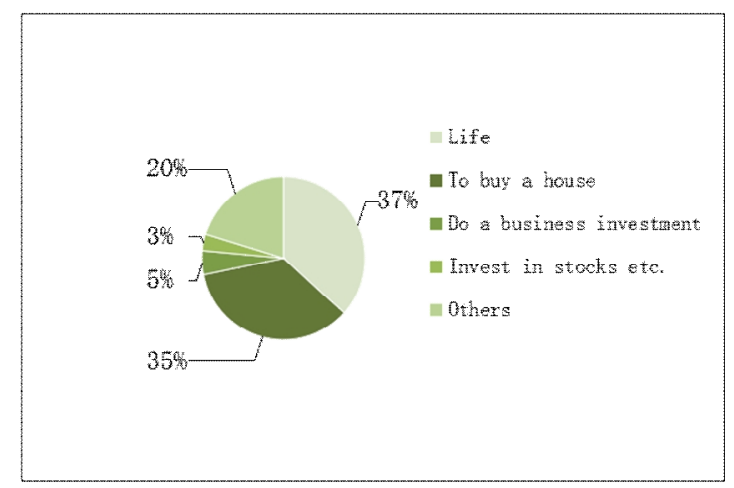

Fig. 2. Main usages of family compensation

\section{At the Perspective of Family Social Security}

According to relevant research, there are three major utilities at the perspective of land function. Those utilities are basic protection, economic benefit and job opportunity which accounting for $38.62 \%$, $19.72 \%$ and $16.95 \%$. So the standards of compensation should not only make the correspondence between land and money, but also consider other utilities of the land such as basic livelihood and job opportunities.

The current land acquisition compensation scheme called "be responded in acquiring land but not people" still exists in Zhejiang Province. 171 respondents which shown on Fig. 3 most concerned about is if their life without security future with $38.1 \%$ in the overall study samples. Otherwise, 97 respondents is worried about unemployment. It is obvious that landless peasants would feel their life 
out of the guarantee after land acquisition. What's more, there are only $12.2 \%$ respondents family members get jobs cause land acquisition as compensation.

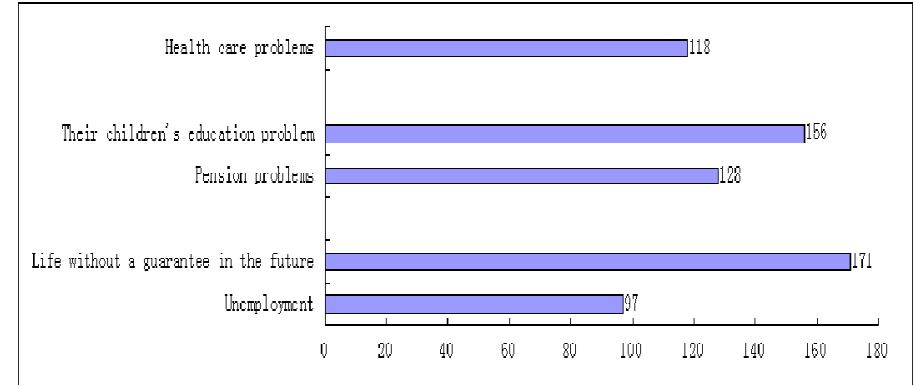

Fig. 3. The most concerned about

To some extent, the department should take great consideration on the sustainable livelihood security and employment of landless peasants. The questionnaire also set a problem what kind of training would landless peasants like to participate in. The data in Fig. 4 shows that accumulated $86.9 \%$ respondents are willing to get involved in learning technical operation and knowledge of financial investment.

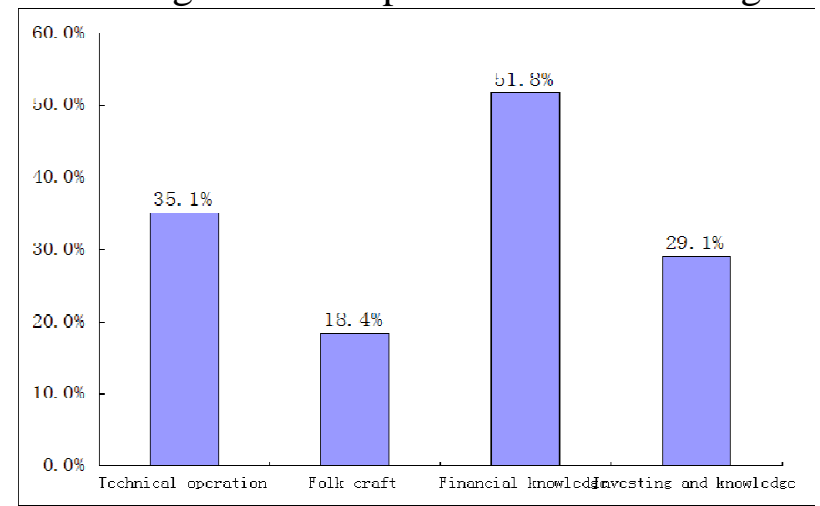

Fig. 4. Things they want to learn

\section{Suggestions}

\section{To Improve the Compensation Scheme of Land Acquisition and House Demolition}

Compared with Zhejiang province, other provinces have started to use the compensation scheme called "Exchange social security for land" which replace single compensation called "Exchange money for land". To put part of monetary compensation to establish the social security system for landless peasants. Through unified management and execution, this way can help landless peasants to optimize their monetary compensation and also provide guarantees for their future life.

\section{To Seek Industrial Support for Urbanization}

Without the support of industry, it is really difficult for urbanization to develop in a right way. In order to provide a good environment of investment and employment for landless peasants, relative departments should establish effective regulations. After the development of industrialization, the society would need a lot of labor which provide lots of job opportunities for landless peasants.

\section{Landless Peasants Should Seek Their Sustainable Development on Their Own}

A good environment is helpful for landless peasants to optimize their human capital. However, landless peasants should realize radically the changeable of their vocations and seek a new direction for themselves which can maximize the utility of their human capital. What's more, landless peasant should improve their technical ability and learn to enhance the quality of their own through practice.

\section{Acknowledgements}

In this paper, the research was sponsored by the soft science key project of Zhejiang Province (2014C25032) and the Zhejiang College Students' innovation program (2014R409033). 


\section{References}

[1] FANG Hun-zhen and HUANG Ke, "The core of the new type of urbanization is to realize the urbanization of people," Journal of the Party School of Tianjin Committee of CPC, vol.4, 2013.

[2] GU Sheng-zu, "What is the meaning of a new-typed urbanization,"News Report, vol.5, 2013.

[3] DENG Da-song, SHI Jing, and HU Hongwei, "Farmers Health Insurance Decision and Family Assets," Journal of Northwest University, vol.5,2009.

[4] SU long. "Lost City" in the process of expansion of farmers' living condition analysis and solution [D]. of Huazhong Agricultural University master's thesis, 2008

[5] SUN Lu, "Landless Farmers into the Community and Community Support", Guangxi Social Sciences, vol.2, 2009.

[6] HUANG Jian-wei and YU Jie, "The Empirical Study of Landless Farmers Long-term Livelihood Problem," Probe, vol.4, 2009.

[7] QIU Shi, YANG Yi-fan and LIN Bing, "The Practice and Experience of Compensation and Resettlement of Landless Farmers", Gansu Nongye, vol.8, 2008.

[8] LU Chun-lian, "Resettlement and compensation of the farmers," Anhui Agriculture Science Bulletin, vol.2, 2007.

[9] SONG song. "China's farmers social guarantee problem inquiry" [D]. Shandong finance and Economics University Master's degree thesis, 2012.

[10]LIU Xiaoxia. "China's urbanization process, the problem of landless peasants of" [D]. of Northeast Normal University doctoral dissertation, 2009 May.

[11]HUANG Jianwei. "Farmer family balance of payments situation and Countermeasures" [J]. "Journal of South China Agricultural University", 2010 fourth (volume ninth). 